and Tobago", of which most of the parts dealing with the Dicotyledons have already been published or are in the press. $\mathrm{He}$ was in charge of the botanical sections of the banana and cocoa research schemes at the College, and in 1948 he went on an expedition to East Africa to collect wild and cultivated species of bananas for extension of the breeding stocks. In 1952 he led an expedition to Colombia for the purpose of collecting wild species of Theobroma. He was also largely responsible for the successful organization of River Estate, the College's field station for cacao research.

Baker (or 'Dick', as he was known to staff and students alike) had a charming personality, a great sense of humour, and an interest in many subjects apart from his profession. Although, perhaps, he sometimes found it difficult to suffer fools gladly, he freely offered his time and experience to those whom he did not consider to be fools, and in this his judgment was seldom, if ever, at fault. The news of his untimely death will be a great shock to the numerous past students of the Imperial College of Tropical Agriculture, now scattered over all parts of the British Commonwealth, who have been taught and inspired by him.

If he was not, in the ordinary sense, a religious man, he whole-heartedly put into practice that great precept, "Whatsoever thy hand findest to do, do it with all thy might". He has been buried in the College cemetery, next to the grave of his former professor, H. R. Briton-Jones, who died in 1936. He is survived by a widow and four daughters.

T. W. KIRKPATRICK

\section{Mr. H. G. Yates}

By the very sudden and untimely death on September 15 of Mr. Henry George Yates, the marine turbine industry has suffered a serious loss. At the age of forty-six he had not reached the peak of his activities, and his abilities as a steam turbine designer in the marine industry were widely recognized and appreciated. $\mathrm{He}$ was widely read, inter. ested in amateur dramatics, and had a happy family life, although his two children are only at the start of their scholastic careers.

The study of vibration was a great hobby of his. Anything from the vibration of a sewing machine at home to the most complex types of vibration occurring in geared turbine systems was strenuously investigated. He had outstanding patience in explaining the more abstruse points in designs. His eyesight had been defective from birth in one eye, but he developed amazing ability in dealing with complex mathematical formulæ in his head.

After a distinguished scholastic career, he graduated at Trinity College, Dublin, in 1930 with first-class moderatorships in mathematics and physics and was afterwards awarded the M.A. degree. He continued at the University as a lecturer in physics for two years before deciding that he would prefer to be an engineer. He served a student apprenticeship with the English Electric Co., Ltd., at its Willans Works, Rugby, and was employed after his apprenticeship in the Turbine Department of the Company. In 1940 a Research Department was set up, and Yates was put in charge of the work. He joined the Parsons and Marine Engineering Turbine Research and Development Association (Pametrada) very near the beginning, and was associated with the growth of the Association, particularly in the work of the Design
Department, in which many designs were prepared for turbine machinery to be installed in important British and foreign ships, the total horse-power of the designs aggregating some seven million. During this time Pametrada acquired a number of foreign licences, which enabled Yates's work to influence building in countries such as Holland and Canada.

Yates was an associate member of the Institution of Mechanical Engineers, Fellow of the Institute of Physics, a member of the American Society of Mechanical Engineers, and at the time of his death was a member of council of the North-East Coast Institution of Engineers and Shipbuilders and chairman of the North-East Branch of the Institute of Physics. Apart from the technical committees of Pametrada on which he was a valued member, he was on the Admiralty Noise Reduction Panel NRP.2, AVGRA Sub-Committee $D$, the Admiralty Gearing Noise Advisory Panel, the Heat Transfer and Heat Exchange Committee of the Mechanical Fngineering Research Organization and Committee $J$ (Power Plant) of the British Electrical and Allied Industries Research Association.

The thing that struck most people meeting him for the first time was his great personal charm and very quiet way in explaining difficult points in design so that they became clear and easy to understand. He is greatly mourned by his colleagues at Pametrada, where he spent the last ten years of his life in charge of the Design Department.

Thomas W. F. Brown

\section{Mr. E. Laurmann}

THE sudden death of Emil Laurmann on November 10 at the age of sixty-four came as a great shock to his friends and colleagues in the Royal Society Mond Laboratory, Cambridge. An Estonian by birth, he was trained as an engineer at Strelitz in Germany but was unable to complete the course owing to the outbreak of war in 1914; he worked for a time at Siemens in Leningrad, and then at the newly organized Polytechnic Institute, where he started his collaboration with Kapitza. In 1922 he followed Kapitza to Cambridge and for many years acted. as his personal assistant, first in the magnetic department of the Cavendish Laboratory and later in the Mond Laboratory. His qualities of inventiveness, skill and patience in all sorts of techniques such as electrical engineering, fine mechanics, photography and the handling of delicate metal erystals, contributed largely to the successful outcome of Kapitza's investigations at very high magnetic fields. After Kapitza's return to the Soviet Union, Laurmann spent a year in Moscow helping to set up similar equipment at the Institute for Physical Problems and collaborated with Kapitza in studies of the Zeeman effect at very high fields.

During the years since the Second World War, Laurmann worked with me in various researches on superconductivity and the magnetic behaviour of metals at low temperatures, and I owe more than I can adequately express in words not only to his technical skill and ingenuity but also to his patience and good nature. Many others in the Mond Laboratory have also benefited from his advice and help, which he always gave willingly in a characteristically quiet and unassuming way; his presence in the Laboratory will be sadly missed. $\mathrm{He}_{e}$ is survived by his widow, a daughter and a son. D. SHOENBERG 